\title{
THE DISCOVERY OF A BEEHIVE AND THE IDENTIFICATION OF APIARIES AMONG THE ANCIENT MAYA
}

\author{
Jarosław Źrałka, Christophe Helmke, Laura Sotelo, and Wiesław Koszkul
}

\begin{abstract}
Recently, an exceptional find was made by the Nakum Archaeological Project in an offering deposited deep within the architectural core of the Precolumbian Maya site of Nakum located in northeastern Guatemala. The form of the object and comparisons made to ethnographic analogs indicate that it is a clay beehive, most probably one of the oldest in the Maya area and in the whole of Mesoamerica. Whether the object was used for its intended function or is an emulation, or skeuomorph, of perishable counterparts, remains unknown. The importance of this find lies in the fact that beekeeping is an activity that is traced with difficulty in archaeology. The present paper discusses the discovery of this artifact at Nakum, which dates to the end of the Preclassic period (ca. 100 BC-AD 250/300), in a wider temporal and spatial context and provides new data on Precolumbian beekeeping. We use a broad comparative vantage, drawing on archaeological, epigraphic, and ethnohistorical sources to discuss Mesoamerican beekeeping and its role in both the daily and the ritual lives of the Maya.
\end{abstract}

Recientemente, el Proyecto Arqueológico Nakum realizó un hallazgo excepcional en el sitio Maya precolombino de Nakum, ubicado en el noreste de Guatemala. Este hallazgo consiste en un artefacto único que formó parte de una ofrenda depositada debajo del núcleo arquitectónico de una de las estructuras excavadas. La forma del objeto, así como comparaciones hechas mediante analogía etnográfica, indican que se trata de una colmena de barro, muy probablemente una de las más antiguas en el área Maya y en toda Mesoamérica. Aún se desconoce si el objeto fue utilizado para alojar una colonia de abejas nativas o si se trata de una representación a escala. La importancia de este hallazgo se debe a que la meliponicultura es una actividad que se rastrea con dificultad arqueológicamente. En este artículo se analiza el hallazgo de Nakum, atribuible cronológicamente a la parte final del periodo Preclásico (ca. 100 aC-250/300 dC), en un contexto temporal y espacial más amplio y se proporciona nueva información sobre el manejo y la crianza de abejas nativas en la época prehispánica. Utilizamos de manera comparativa un amplio cuerpo de datos, recurriendo a fuentes arqueológicas, epigráficas y etnohistóricas para analizar la meliponicultura mesoamericana y su papel en la vida diaria y ritual de los Mayas.

$\mathrm{I}$ $\mathrm{n}$ this article, we discuss a rare Precolumbian ceramic artifact that in our opinion may represent a genuine beehive or a ceramic skeuomorph. The specimen was discovered as part of a cache or offering placed below one of the structures at the Maya site of Nakum located in northeastern Guatemala. Archaeological, ethnohistorical, and ethnographic evidence from the Maya area support our interpretation and indicate that the Nakum piece could well be the oldest beehive not only from the Maya area, but from all of Mesoamerica. Here, we present our discovery in a broader comparative and cultural context, providing important information about Precolumbian and modern Maya beekeeping.

Nakum is a secondary site located in the Yaxha-Nakum-Naranjo National Park in the Peten Department of Guatemala (Figure 1). The

Jarosław Źrałka — Institute of Archaeology, Jagiellonian University, Kraków, 31-007, Poland (j.zralka@uj.edu.pl; corresponding author)

Christophe Helmke Institute of Cross-cultural and Regional Studies, University of Copenhagen, DK-2300 Copenhagen

S, Denmark (cgbh@hum.ku.dk)

Laura Sotelo - Centro de Estudios Mayas, Instituto de Investigaciones Filológicas, Universidad Nacional Autónoma de México, Ciudad de Mexico, C.P. 04510, Mexico (biblos.2@att.net.mx)

Wiesław Koszkul — Institute of Archaeology, Jagiellonian University, Kraków, 31-007, Poland (wkoszkul@wp.pl)

Latin American Antiquity 29(3), 2018, pp. 514-531

Copyright @ 2018 by the Society for American Archaeology doi:10.1017/laq.2018.21 


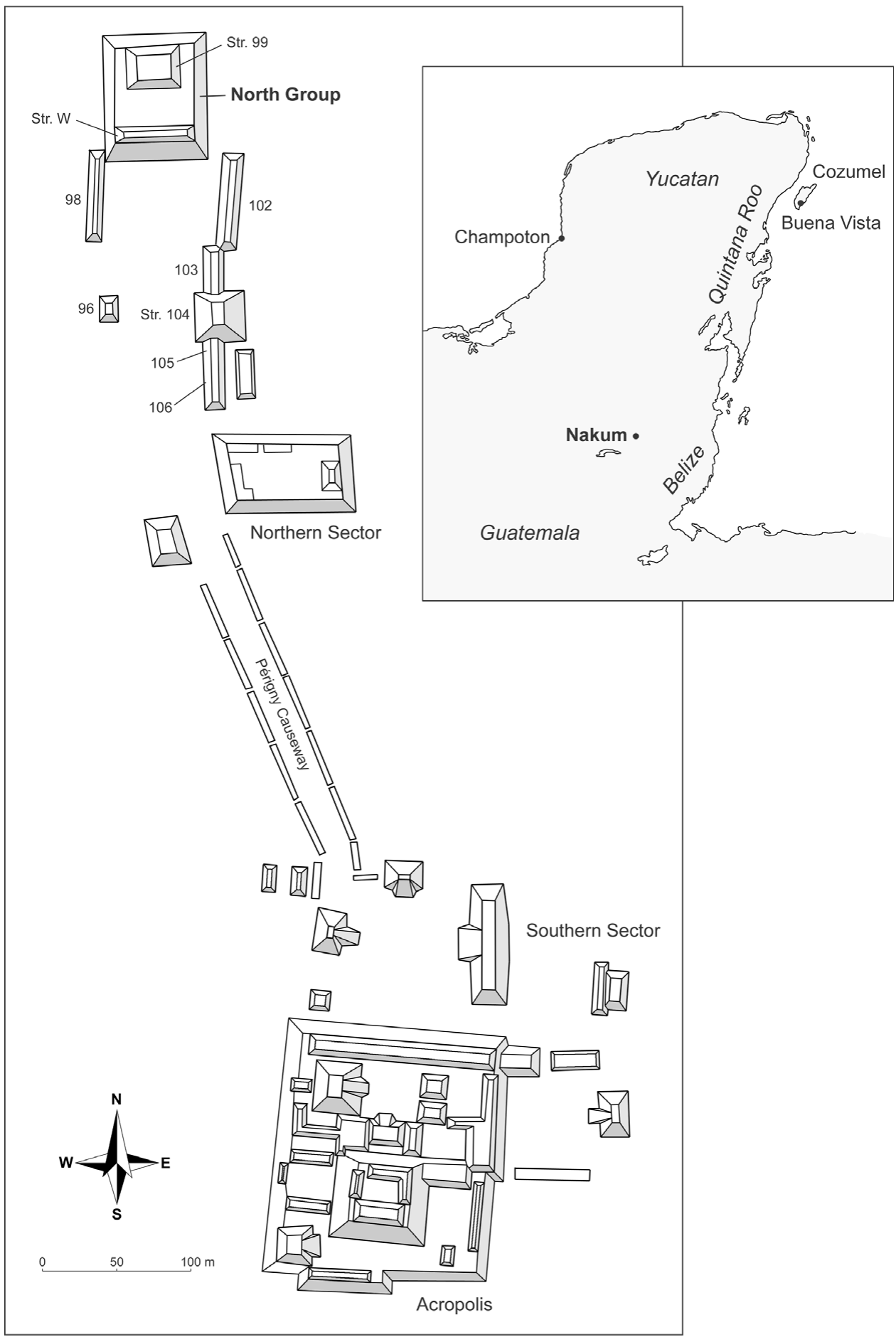

Figure 1. Map of Nakum featuring two major sectors of the site. Inset: Location of Nakum in the Maya area indicating modern countries and localities as well as some of the sites mentioned in the text (Maps by Christophe Helmke). 
site has been known since 1905, when it was first reported to the scientific world by the French count Maurice de Périgny (1906). Since Périgny's visit, the site has been explored by several expeditions and scholars, among them Alfred Tozzer and Raymond Merwin of the Peabody Museum of Harvard University (Tozzer 1913), Sylvanus Morley of the Carnegie Institution of Washington (Morley 1938-1939), and more recently by Nicholas Hellmuth (1992). In 1989, the Guatemalan Institute of Anthropology and History (IDAEH) initiated activities aimed at consolidating the most deteriorated buildings and backfilling of looters' trenches followed by archaeological works (Hermes 2002; Hermes and Calderón 2003; Noriega 1999; Noriega and Hermes 2000; Noriega and Quintana 2002; Quintana and Wurster 2002). Since 2006, Nakum has been the focus of archaeological excavations conducted by the Institute of Archaeology of the Jagiellonian University, Krakow, Poland.

Nakum was first settled during the early Middle Preclassic period (1000-700 BC) and experienced a continuous growth until the end of the Classic period (c. 10th century AD). The first examples of monumental architecture at Nakum were raised during the late Middle Preclassic and Late Preclassic (600 BC-AD 250/300). These included ceremonial complexes some of which were decorated with mythic narratives: stucco masks featuring the most important supernatural beings. It was during the Classic period (dating to $\mathrm{AD} 250 / 300-950$ and characterized by the demographic and cultural peak of the ancient Maya civilization) when most structures visible now at Nakum, such as pyramids, temples and palaces, were built.

Nakum consists of two major architectural complexes (the Northern and Southern Sectors) connected by a $250 \mathrm{~m}$ long causeway (Périgny Causeway; Figure 1). The Northern Sector of Nakum is made up of a vast plaza (North Plaza) surrounded by several architectural complexes (North Group, West Group, and Merwin Group), two elongated platforms (Structures 98 and 102), and one pyramidal temple (Structure X, or 104) that formed an E-Group complex with several neighboring constructions (Structures 103, 105, and 96). The Southern Sector of Nakum encompasses several large plazas (Central Plaza, East
Plaza, and Southeast Plaza) surrounded by large pyramidal temples (Structures A, B, C, V, and $\mathrm{U})$ and an enormous acropolis that consists of a large platform surmounted by 16 courtyards with more than 40 constructions, most of which had residential as well as regal-ritual functions, consonant with Maya palaces.

\section{Archaeological Context and Dating of the Artifact}

Structure 99, where the discovery was made, is located in the North Group. It consists of a large platform that supports several buildings: one long range structure (Structure $\mathrm{W}$ ), two low mounds (Structures 98 and 100), and one large platform (Structure 99), ca. $7 \mathrm{~m}$ high, which during its last architectural stage (in the Terminal Classic, circa AD 800-900/950) was surmounted by three superstructures (Figure $2 b-c$ ). The latter construction was extensively investigated during the recent research of the Nakum Archaeological Project when two tunnels, several trenches, test pits, and extensive clearing excavations were carried out (Źrałka et al. 2008:77-92, 2014). They revealed that Structure 99 started as a low platform surmounted by a single chamber with a stairway on its southern face (the whole construction was denominated by us as Structure 99 Sub1). Structure 99 Sub- 1 was 7 to $8 \mathrm{~m}$ long (N-S); however, its exact width is unknown (Figure $2 \mathrm{~d}$ ). Structure 99 Sub-1 was constructed during the Late Preclassic period (possibly between 300 and $100 \mathrm{BC}$ ). Excavations revealed an offering placed on the main N-S axis of Structure 99 Sub-1, just at the base of its stair (Offering 9). It was cached in a small cist atop a level of a stuccoed floor (Floor 4). The cache cist occupied an area approximately 0.85 in in diameter, covered by two large stone slabs (Figure 3). Offering 9 included nine unbaked clay heads placed in a circle. These artifacts may represent Underworld deities or the Nine Lords of the Night frequently mentioned in Classic Maya inscriptions (Źrałka et al. 2008, 2012). In the middle of this circle, a jade pendant representing a monkey head and a spherical jade bead were found. Offering 9 also included a stingray spine with a sharp, notched edge, which the Maya had used for ritual bloodletting. The spine was ritually broken and placed on 

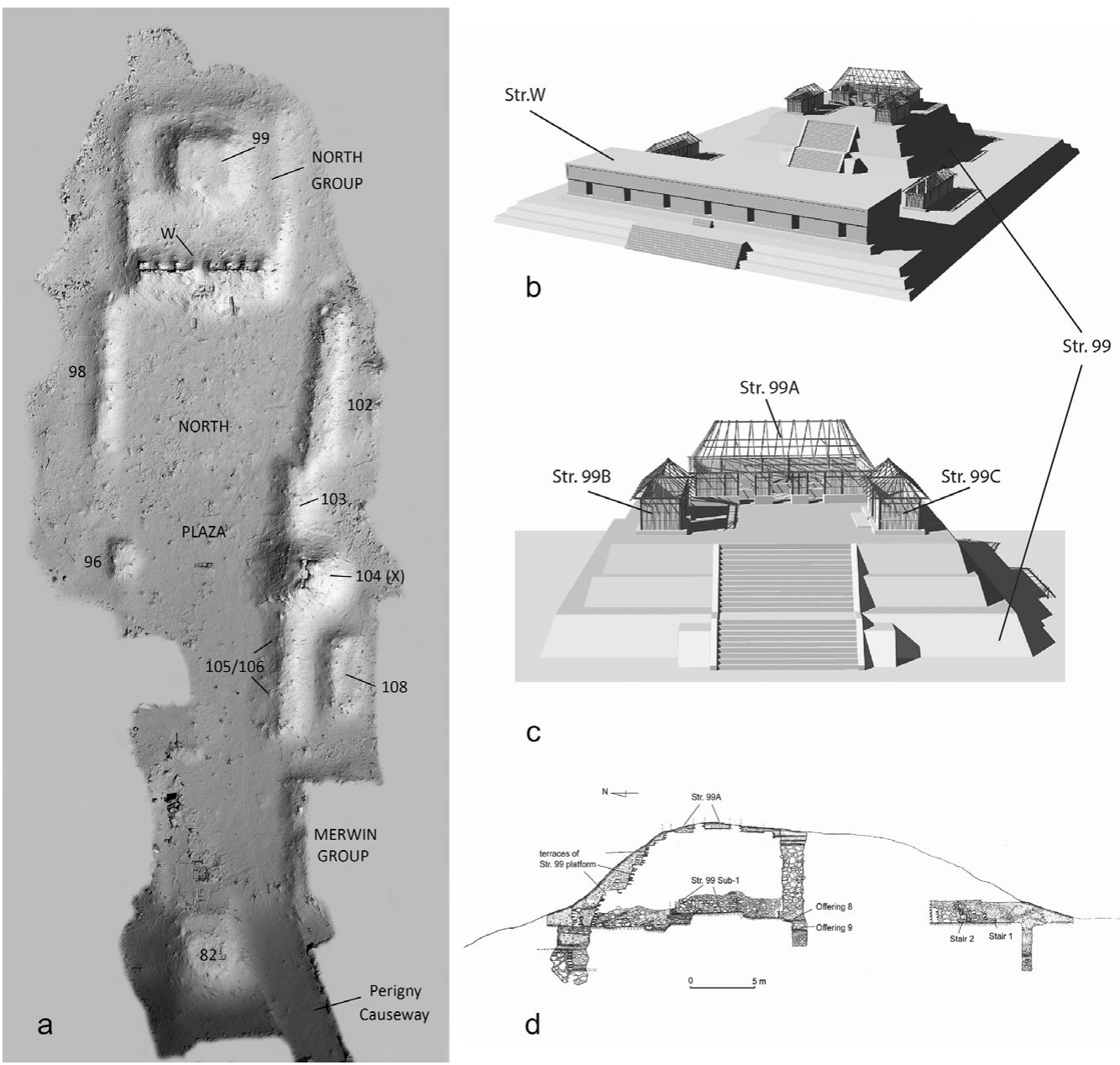

C

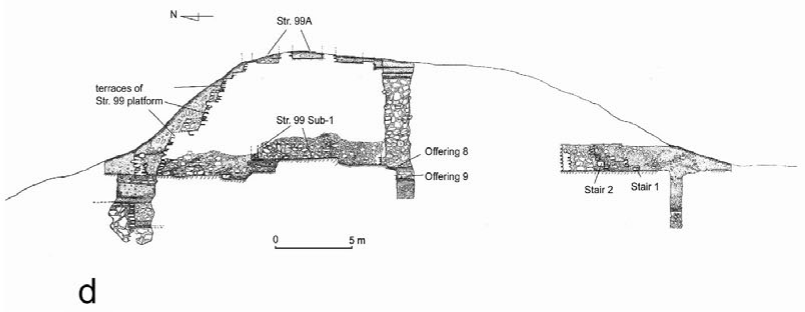

Figure 2. a) 3-D scan of the North Group of Nakum and Structure 99 (by Bolesław Zych, the Nakum Archaeological Project); b-c) Isometric reconstructions of the North Group during the Terminal Classic (models by Anna Kozińska and Anna Kaseja, the Nakum Archaeological Project); d) Cross-section of Structure 99 featuring the location of substructure (99 Sub-1) and Offering 9 described in this article (drawing by Bogumił Pilarski, Aleksander Danecki, Paweł Kurzawa, and Jarosław Źrałka).

one of the clay heads. Moreover, the eastern side of the cist was occupied by an interesting artifact-a barrel-shaped ceramic tube with two ceramic covers at each end, which we interpret as a beehive (see Figures $3 d$ and 4). It is based on this context and the associated artifacts that we surmise that this beehive was symbolically tied to the deities that would be propitiated by such an offering. Particular times of the year were dedicated to such deities, as revealed by ethnohistorical sources. Based on the ceramics and stratigraphy, Offering 9 can be situated in the second part of the Late Preclassic period or during the Protoclassic period (ca. 100 BC-AD 300). Offering 9 was covered by the stuccoed floor (no. 3) on which some time later the Maya placed another offering (no. 8). The latter offering was also dated using ceramics to the Protoclassic phase (Źrałka et al. 2008:84-87, 2012:31-32, 2014:107). This dating was further confirmed by one radiocarbon date of AD 80-260 ( $2 \sigma$ cal.; Źrałka et al. 2014: 107). All archaeological data indicate that Offering 9 and the ceramic tube date to the Terminal Preclassic or Protoclassic period. 

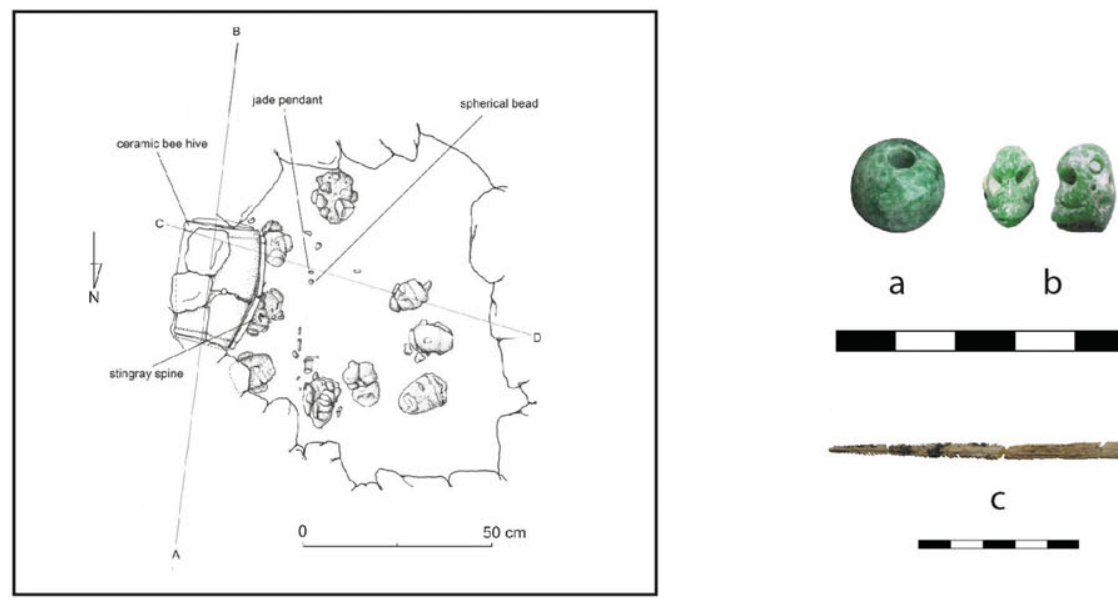

a $\quad b$

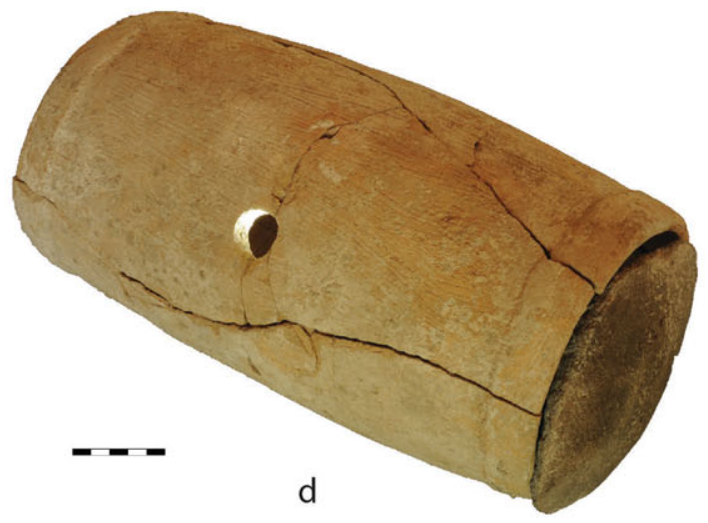

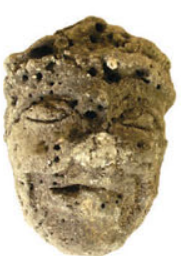

e

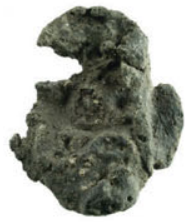

i

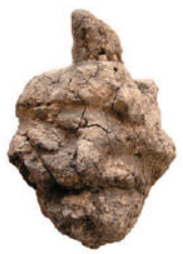

f
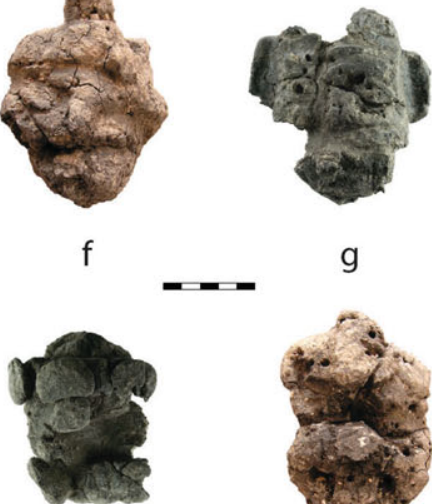

j g

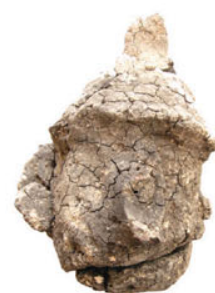

h

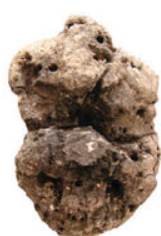

k

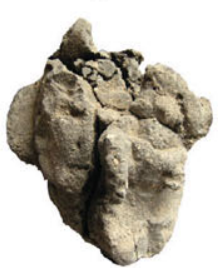

I

Figure 3. Plan of Nakum Offering 9, dated to the Protoclassic, showing the disposition of the artifacts found within, a) jade bead; b) jade pendant in the form of monkey head; c) stingray spine; d) ceramic beehive; e-l) eight of the nine heads made of unbaked clay (drawing by Katarzyna Radnicka, photographs by Robert Słaboński and Jarosław Źrałka). (Color online) 

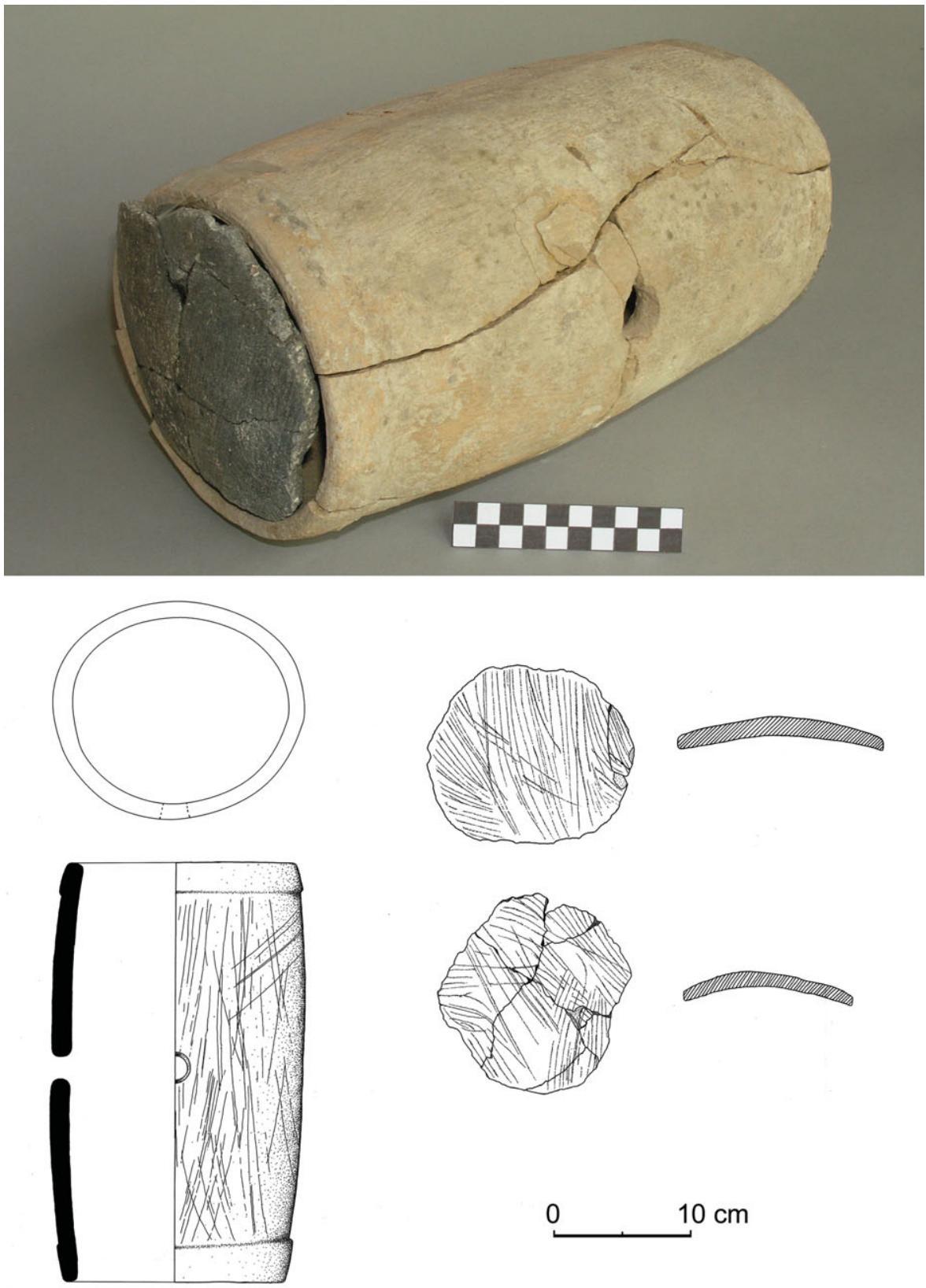

Figure 4. The ceramic beehive from Nakum Offering 9 (photograph by Jarosław Źrałka, drawings by Katarzyna Radnicka and Piotr Kołodziejczyk). (Color online)

In other words, they are approximately 2,000 years old.

\section{The Nakum Beehive and Its Counterparts}

The ceramic tube from Offering 9 is $30.7 \mathrm{~cm}$ long with a maximum diameter of $18 \mathrm{~cm}$. Its walls are relatively thick, measuring as much as $1.5 \mathrm{~cm}$. It bears a single hole $3 \mathrm{~cm}$ in diameter in the middle. The artifact was formed of light ceramic paste devoid of any slip, but with a striated exterior. The piece can be ascribed to the Triunfo Striated ceramic type (Variety: Morfin, no. PANC 020 according to the Nakum Archaeological 


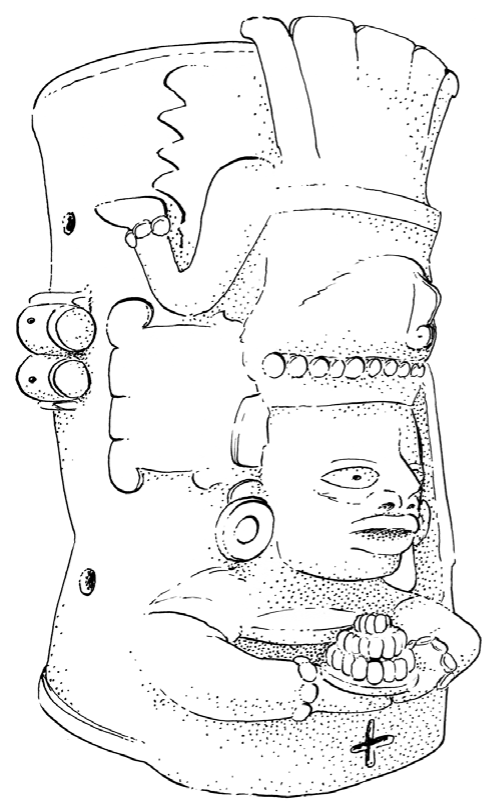

a

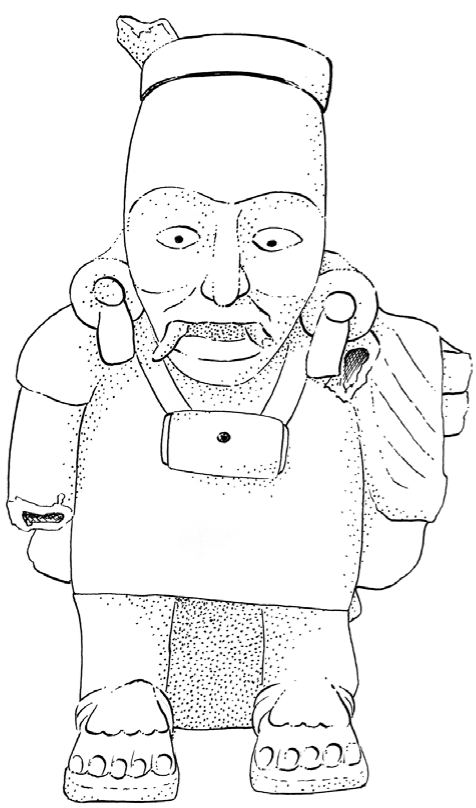

b

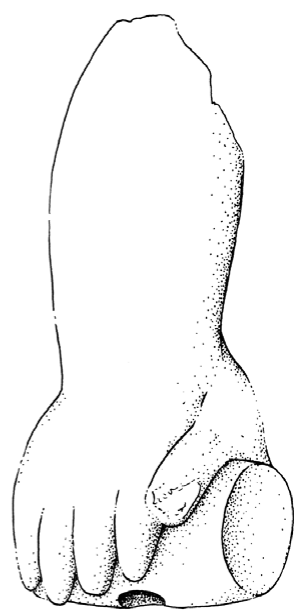

C

Figure 5. Artifacts depicting miniature beehives similar to the object found in Nakum Offering 9: a) Ceramic censer of Chen Mul type representing a so-called Diving God who holds honeycomb cells in his hands, with two pairs of miniature beehives shown on the side of the censer; b) another Chen Mul censer with representation of a deity wearing a miniature beehive on his necklace; c) a fragment of figurine depicting human arm grasping a beehive (drawings by Christophe Helmke, based on photographs by Laura Sotelo and after Virchow 1887: Figure 2).

Project numeration; Bernard Hermes, personal communication 2017). Two ceramic disks or covers that accompanied the tube were made of blackish ceramic paste and represent Sapote Striated ceramic type (PANC 021 and 022; see Smith and Gifford 1966:162). The covers measure 16.7 and $17.0 \mathrm{~cm}$ in diameter, respectively. The inside exhibits no traces of organic materials or any kind of discoloration, suggesting that it was not used as an actual, functional beehive. Samples taken from the inside of the beehive proved inconclusive with regards to organic material. Nevertheless, it remains possible that the inside of the beehive was scraped clean before it was deposited within the cache or that its organic content has not survived.

The Nakum specimen does not readily compare to other artifacts from the Maya area. The nearest counterparts are miniature beehive embellishments found on larger objects, particularly incense burners known from the northern Maya lowlands, representing the so-called
Postclassic Chen Mul style (Figure 5a-b). Both incense burners were excavated on Cozumel Island, which was an important center for the production of honey and wax in the Late Postclassic period (Patel 2005).

The first of these censers (originally part of the collections of the Museo Palacio Cantón in Mérida) features a so-called Diving God holding honeycomb cells, or alveoli, in its hands, which evidently stem from the interior of a beehive (Figure 5a). Alveoli are often removed from the beehive and placed in other horizontal wooden beehives to seed new colonies. On both sides of the deity, there are two pairs of small beehives. This further supports the interpretation that the censer was a ritual object specifically related to beekeeping. The beehives from this artifact are well rendered and are depicted as overlapping, with a central hole and two stoppers at both ends (see Wallace 1978).

Another example of an object similar in form to the Nakum piece is exhibited in the Maya 
Hall at the National Museum of Anthropology in Mexico City. This, too, is a censer, and its front bears the representation of an aged male deity. The deity wears a necklace with a beehive placed horizontally on his chest (Figure 5b).

There is yet one more artifact that may feature a miniature beehive similar to the example excavated at Nakum. It was drawn to our attention by Estella Weiss-Krejci, who points to an account by Rudolf Virchow-a German doctor, anthropologist and prehistorian-who in 1887 wrote about a "Maya skull from Merida" that was taken from a grave by a man named $\mathrm{H}$. Curschmann. According to Virchow, the skull was accompanied by fragments of a figurine, perhaps another figurative censer. One of these fragments features a human arm grasping an elongated, oval, barrel-like object with a small hole in the middle (Figure 5c). The latter piece is similar to the aforementioned beehives, and concomitantly, Virchow states that the locals considered the object in the hand of the figurine to be a beehive (Virchow 1887:451-455).

Both the Nakum artifact excavated in Offering 9, as well as the above-described miniature versions of beehives decorating the incense burners and the clay figurine, have counterparts in beehives known ethnographically and used today by various native populations of the northern Maya lowlands (Mayer 2009; Źrałka et al. 2014:100-101). Such beehives are known among the modern Yucatec Maya as jobon, literally "something hollow, a cavity" (or as jobonil, and even jobnil; see Barrera Vásquez 1980:214215; Bastarrachea Manzano et al. 1992:22). Alternatively, such beehives are also known more descriptively as jobon-che, "hollow-tree" or uche' el kaab, that is "tree trunk of bees" (Barrera Vásquez 1980:85, 215). As the names imply, such jobon are made of hollow, wooden logs, the openings on either end closed off with two covers (Figure 6). The covers are manufactured of either wood or stone and are held in place by earth or dried mud. They can be removed at any time to collect honey and wax. These jobon bear in their medial section a small hole through which bees can enter the log, serving as the primary entry point to the hive. Such jobon are stored by modern Maya on A-shaped wooden racks, sheltered in simple open huts covered by thatch roofs made of palm leaves, designated as yotoch $k a a b$ or "home of bees" in Yukatek (see Mayer 2009:98; Figure 6a). The Yukatekan jobon are all very similar in size; their lengths typically range between 50 and $60 \mathrm{~cm}$, and their diameters are between 20 and $30 \mathrm{~cm}$ (Mayer 2009; Źrałka et al. 2014:101). They exhibit relatively thick walls ranging around $4 \mathrm{~cm}$ and a central hole that is usually less than $1.5 \mathrm{~cm}$ in diameter. Based on these parameters, the covers sealing jobon have an average size of $18 \mathrm{~cm}$ in diameter.

The relationship between humans and bees is one characterized by the acquisition of honey, particularly from the wild populations and from domesticated ones raised in beehives. This dichotomy also existed in prehispanic Mesoamerica and endures to some extent in traditional communities today. Wild bees usually nest in the cavities of trees or the interior of tree trunks, but they may also live between rocks, boulders, as well as below the earth, as is the case of Geotrigona acapulconis (García Magdaleno 2013:17, 20, 63). Currently, the jobon are used to keep domesticated bees. Nevertheless, domesticated bees can be also kept in large ceramic jars and in dried bottle gourds. The former way of keeping bees is typical for the northern part of Puebla in Mexico and may have been present in the Maya area during Precolumbian times, as may be surmised from ethnohistorical sources from Guatemala (García Magdaleno 2013:18, 28, 72). In his account of the natural history of Guatemala, dating to the beginning of the 18th century, the Spanish Fray Francisco Ximénez mentions the use of ceramic jars as beehives among the Maya of Rabinal (Ximénez 1967:113-114). Bottle gourds used as beehives, in contrast, have been documented in some parts of Guatemala (García Magdaleno 2013:18) that are also mentioned by Fray Ximénez (Ximénez 1967).

Both ancient and modern jobon are used to keep endemic stingless bees, mostly the black bees of the Melipona beecheii species that in Yukatek Mayan are named kolel kaab or xunan kaab (literally "lady bee" and "woman bee"). Whereas bees of the Melipona sp. hold a privileged place in Yucatec Maya communities, there are many other local species of bees that produce honey that is at times harvested for consumption. 


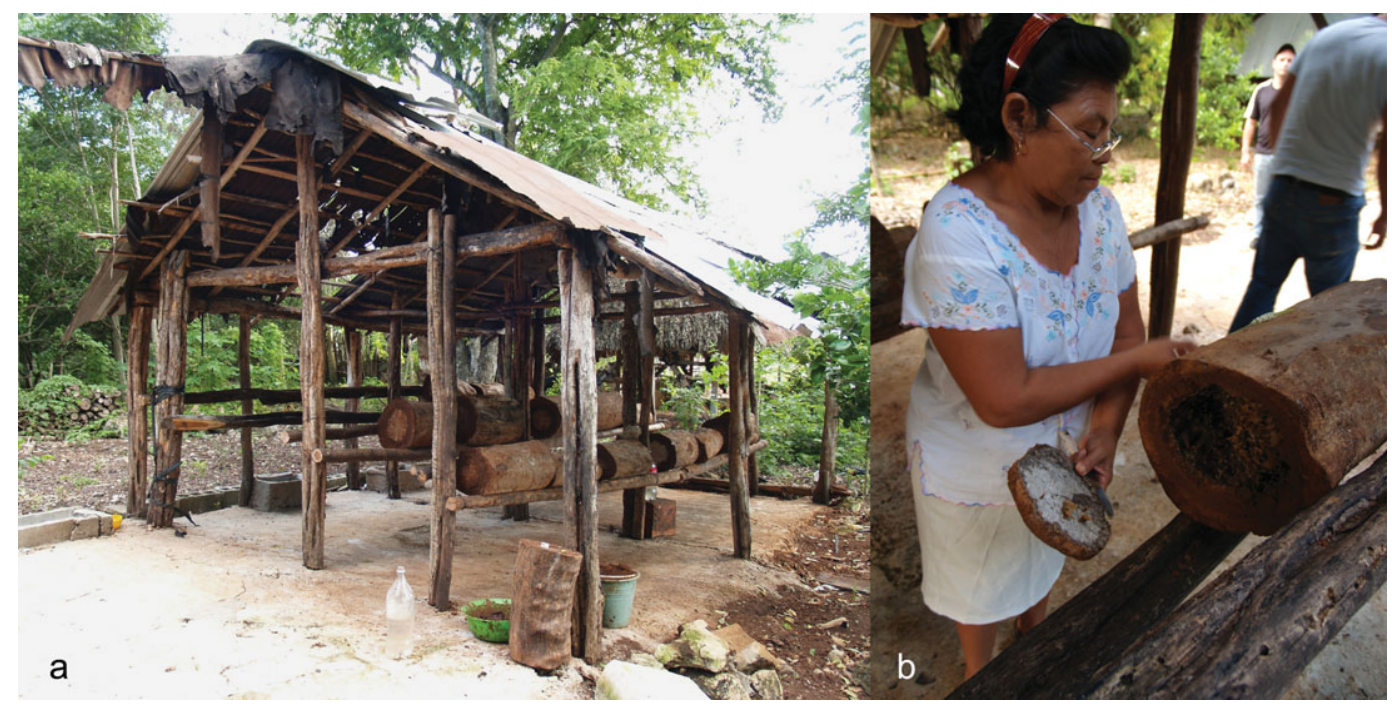

Figure 6. a) Modern apiary with jobon at Ich Ek, Yucatan, Mexico b) Woman closing jobon (a beehive made of tree trunk) full of honey cells, Ich Ek, Yucatan, Mexico (photographs courtesy of Lorraine Williams Beck). (Color online)

Among these is another species of stingless bees Partamona bilineata, also native to the area, which are dark brown to black and are referred to as $x$-nuk ("old woman"). The cognate of the Yukatek kab in Ch'olan languages is chab, exhibiting a $k>c h$ palatization shift. A Spanish term abeja real ("royal bee") is also used to describe certain stingless bees of Yucatan (Mayer 2009:99) and Guatemala (Dardón et al. 2013). In contrast, wild bees, thought of as feral and said to live underground, are known as báalam kaab or "jaguar bees" (Barrera Vásquez 1980:32; see also López Medel 1990:50).

Another honey-producing and stingless bee, the Tetragonisca angustula, is distinguished by its partial yellowish coloration and even smaller size (relative to Melipona sp.). This same type of bee is more common in the central Maya lowlands, and is described in detail by Fray Francisco Ximénez (1967:113-118), who calls them doncellitas ("little maidens") and also provides the lexeme $\langle u z c a b\rangle$ for the same bee in a local K'iche'an language. Although the name was provided in colonial orthography, the term can be etymologized as /us-kaab/ or /u's$\mathrm{kab} /$ in K' iche' and Kaqchikel, respectively, for "fly-bee" or alternatively as "fly-honey." This description is rather suitable, considering the flight of these bees compares closely to that of flies. On account of their size, the honey yield of T. angustula is commensurate and also stands out for its lighter color, high $\mathrm{pH}$, and sucrose content (Dardón et al. 2013:406).

There is evidence of large-scale intensive farming of stingless bees (Meliponini) from the precolumbian era up to present times in the northern Maya lowlands, and especially along the eastern coast of the Yucatan Peninsula (Nárez 1988). Nevertheless, the introduction of the European honey bee, the so-called Italian bee (Apis mellifera), to the Yucatan, as well as other factors (such as overexploitation of the local environment, deforestation, overharvesting plus the increasing use of pesticides), has led to an abrupt decline in the native species, particularly M. beecheii (Villanueva-G. et al. 2005). This introduction has also brought about a change in the appearance of beehives, because the new species are kept in wooden box-like beehives (of which there are many types, including the Langstroth hive, that is in many ways the modern standard). Nowadays, very few Maya communities have apiaries of Melipona beecheii using the traditional beehives made of hollow wooden logs. Given the decline of endemic populations and their decreasing use in production and harvest of honey, there is mounting apprehension that $M$. beecheii may completely disappear from 
the Maya lowlands (see Ayala et al. 2013; Mayer 2009). Serving as countermeasures, are the government-run programs and the sale of Melipona sp. honey in state-run craft stores in larger cities in the Yucatan.

Apart from the artifacts discussed, no other comparable beehives are known, yet excavations at some Yucatecan sites (e.g., various sites of the Cozumel Island such as Buena Vista, Aguada Grande, or San Gervasio) and others in modern-day Campeche, Mexico (Villamar 1 and 2 as well as Playa Esmeralda in proximity to Champoton) have revealed circular limestone or coral disks that most probably were used as stoppers or covers of beehives (Imre et al. 2010; Suárez et al. 2010:754, Figure 6; Wallace 1978). The beehives themselves have not been recovered because these were undoubtedly made of perishable materials (wooden logs). Besides, comparable artifacts such as disks made of either stone or pottery have been reported from several Maya sites of the southern Lowlands and at least some of them might be connected with beehives, functioning as stoppers (see Kováč et al. 2016: Figure 4b-c; Źrałka et al. 2014:105107). Likewise, modern jobon, although made of wooden logs, frequently bear covers of stone, comparable to the objects excavated as part of archaeological works (Wallace 1978). Moreover, Spanish chroniclers (Bernal Díaz del Castillo and Fernández de Oviedo) who saw Maya apiaries from the northeastern part of Yucatan (Cozumel Island) describe that hives were made of tree trunks and they had stone plugs on both ends (Imre et al. 2010:44). Similarly, ceramic disks of comparable diameter to the stoppers of modern jobon have been found in a series of caves in Guatemala and Belize, although in general these have been interpreted as makeshift lids for censers (see Brady 1989; Helmke 2009). Large concentrations of such objects were found within many masonry buildings, especially on Cozumel island (as well as in mainland Yucatan Peninsula), serving as a basis for the identification of possible apiaries (Imre et al. 2010; Wallace 1978). Such constructions have circular or semicircular shapes, ranging in diameter between ca. 7 and $20 \mathrm{~m}$, with recently documented examples at a coastal site of Quintana Roo (Martos López 2002:63-65), and as many as 36 such structures at the site of Buena Vista, on Cozumel island, in Mexico (Batun Alpuche 2009:187-189).

\section{Ethnohistorical Sources}

One of the most salient sources on Yucatecan culture was provided by Fray Diego de Landa, the second bishop of Yucatan in the 1570s, in his invaluable work entitled Relación de las cosas de Yucatán (Chuchiak 2005; Tozzer 1941; see also Restall and Chuchiak 2002). In this work, he provides an overview of the environment, flora and fauna of these foreign lands, and also provides an overview of Yucatec Maya calendrical rites and the associated calendar. As part of this, he notes that in the fifth month of the solar calendar, named Sek, rituals were performed to quadripartite deities associated with the cardinal directions, and in particular to one Jobnil, an eponymous deity associated with beehives. The offerings included small balls of incense, each painted with small "effigies of honey" or "drawings of honey" (literally figuras de miel), to which this feast was dedicated. Here we should remark that the word figuras is used in the original, with Landa describing designs painted on the balls as unclear, leading to multiple translations. We presume that he may mean that the logogram KAB, read kaab, was painted on each of the spheres, but his understanding of Maya writing was not particularly astute (Stuart 1988). The celebrations were concluded with pomp and "wine," presumably honey-infused alcoholic beverages. Such beverages, and honey, were offered in abundance by the owners of the beehives (de Landa 1566:Fol. 41v-42r). In addition, comparable rituals were performed in the eighth month, named $\mathrm{Mol}$, wherein beekeepers made rounds to the beehives to make offerings, so that the gods would provide flowers for the bees (de Landa 1566:Fol. 43r). Besides these observations, further on he provides an insightful paragraph that introduces the stingless bees of the land to his European readers:

There are two types of bees and both are much smaller than ours. The largest of these breed in hives, which are very small; They do not make a honeycomb like ours but certain alveoli resembling walnuts of wax, all joined 
one to the other, full of honey. To harvest these they need only open the hive and burst these alveoli open with a stick, and so flows [Fol. 56r / 56v] the honey and they recover the wax when it seems right to them. The others are raised in the wilds [literally montes "mountains, hills"], in the hollows of trees and stones, and there they look for the wax of which, and the honey, that this land abounds, and the honey is very good, except that owing to the fertility of the pastures the honey is slightly watery and it is necessary to boil it over the fire making it very good and very hard. The wax is good except it is very smoky and has never been quite right for whatever purpose, and in some provinces is much more yellow owing to the flowers. They do not bite these bees nor do (anything) when they are poorly harvested.

(de Landa 1566:Fol. 56r-56v; translation ours)

This account greatly resonates with that provided by Tomás López Medel, who served as judicial auditor of the Real Audiencia (royal appellate court) in Guatemala in 1549 and went on to be designated as visiting functionary of the province of Yucatan and to serve in the government of the region between 1552 and 1553, until he was dispatched to Bogota in 1557. In his treatise entitled De los tres elementos, he recounts his encounters with native Maya bees, with great wonderment:

Honey is produced in the warmer lowlands as well as within the colder highlands and it is so excellent in many areas that it exceeds that of Spain, especially if it is of the lowlands and made by domesticated bees in individual beehives [...] as in Guatemala [...] as well as in certain parts of Mexico. Throughout the province of Yucatan there is so much in the orchards and in the hills and in the hollows of the earth that it is a wonderful thing to see; it seems that it would fit that land, as regards this, that which the Holy Scripture states: fluentem lac et mel. There is no part of the Indies, nor do I believe Spain, where as much honey and wax are produced as in the province of Yucatan, and therefore the Indians and natives of those provinces $[\ldots]$ are not content with honey and wax brought from the mountains and common places, but also have many hives in their houses and other places. And aside from there and Guatemala, there are few or no parts where the Indians do not domesticate the bees and bring them out of the community of all.

(López Medel 1990:49; translation ours)

\section{Epigraphic Sources}

In addition to ethnographic and ethnohistorical data concerning bees and beekeeping, one of the most importance sources to understanding the role and importance of bees in ancient Maya culture is the manuscript known as the Madrid Codex. This document was produced in the first few decades following the Spanish conquest (Chuchiak 2004) and served as a divinatory almanac for ritual specialists (Bricker 1997; Vail and Aveni 2004). It is made of bark paper, covered with a thin layer of gesso and painted with black, red, blue, green, and white pigments (see Buti et al. 2014). It is the longest glyphic codex; fully extended, it measures $6.83 \mathrm{~m}$. It is folded in accordion fashion into 56 pages and is painted on both sides, forming a total of 112 pages. This lengthy manuscript is divided into a series of chapters, including one devoted to astronomical tables of the Mars cycle (pp. 1-9), another focused on agricultural deities (pp. 1029), followed by a section on calamities and natural disasters (pp. 30-33), calendrical sections focused on various cycles (pp. 34-37, 75-78), and one on sacrificial rituals (pp. 50-56). There are also chapters outlining the deeds and auguries of deities (pp. 57-74 and 79-88) where the thunder deity Cháak figures prominently. What most distinguishes the Madrid from the other extant codices is the inclusion of almanacs pertaining to deer hunting (pp. 38-49), the shaping of wooden figures, masks and idols (pp. 89-101), weaving (p. 102), and beekeeping (pp. 103-112; Bricker and Vail 1997; Ciaramella 1999, 2002, 2004; Nielsen et al. 2016:76-77; Vail 1994). As such, even activities that we may consider prosaic and quotidian deserved the same kind of attentive reflection, planning, and divination as any other wholly ritual activity. 
This latter section is aptly known as the Beekeeping Almanac and concerns the animals that prey on beehives, the harvesting and collection of honey, as well as the various offerings made to apiaries on particular calendrical stations, making it clear what dates were suitable for which types of ritual actions (see Ciaramella 2002; Sotelo 2002; Vail 1994). As such, this source provides an apt parallel to the information provided by de Landa, but from an emic perspective. Every segment of the almanac is initiated by a range of dates in the 260-day ritual calendar known as the Tzolk'in (Bricker 1997:2-5; Vail 1994:52-65; Vail and Aveni 2004). Each clause begins with a verb describing the type of ritual action and is followed by a reference to bees, the name of the particular deity presiding over the range of dates, and the associated augury. Each text is paired with a small figurative vignette (Figure 7).

Besides fairly accurate depictions of bees, these examples also provide representations of the exterior and interior parts of $\log$ hives. Beehive exteriors are shown as rectangles having the color of honey with possible stoppers depicted as white, vertical strips or bands on both ends of the hives. The Madrid Codex also contains numerous depictions of the interior of the beehives, which are depicted as rectangles with a white background overlain by egg-shaped jars (to denote the alveoli made of beeswax where the bees store pollen and honey). In addition to the depictions of the logs or jobon themselves, are several cases wherein bees are depicted as living within diminutive houses with thatched roofs, as though personified, which the glyphic captions make clear are otoch ukab, "home of the bees" (Figure 8b).

To name only a few, some of the deities associated with the beekeeping almanac include the supreme celestial deity Itzamnaj, Cháak, the personification of thunder, Yax Báalam a mythic hero known from epic tales, and an array of death deities, evidently tied to negative auguries (see Taube 1992). The wild variety of deities associated with the manifold dates of the almanac are at times also depicted making the offerings to the bees, as though human officiants and the supernatural were one in the eyes of the bees (Figure 8a). One forms the impression that certain apiaries may have been thought of as operated by distinct deities, or alternatively dedicated to particular supernatural entities.

In addition to male deities, there are numerous examples of a female divinity known as Goddess I, an entity that is thought to be tied to the moon (Taube 1992:64-69). Much like her male counterparts, she is depicted as a beekeeper. She is invoked in an incantation to protect the beehive from ailments and harm (Bolles 1982). Akin to the goddesses that are said to guard the beehive in modern Yucatec Maya lore (Mayer 2009), the old Moon Goddess is the keeper of the beehive. Here she harvests the honey, because the beehive is open to reveal its honeycomb, an activity associated with the waning moon, according to ethnographic accounts (Báez-Jorge 1988:247248; Milbrath 2010:30-31, 105-155).

Among the ritual actions associated with bees in the Madrid Codex we read a variety of verbs, including dedicatory rituals for the beehives themselves, recorded as och-otoch, "houseentering," referring to the entry of sacral fire and smoke as part of inaugural rites (see Stuart 1998:384-389). In addition, the verbs and ritual actions recorded in the almanac refer to the establishment of hives, their dedication to particular deities, the arrival of bees, increasing production of honey and its subsequent harvest, the sweeping of hives, and possibly their relocation (see Ciaramella 2002; Vail 1994).

Offerings made to the bees, or at least presented to the beehives, include incense and stacks of small steamed tamales, occasionally filled with beans, stewed turkey, venison, or iguana meat (Ciaramella 2002; Vail 1994). Good auguries are tied with poetic expressions known as difrasismos or kennings, such as $u k^{\prime}$-we', literally "drink-eat" for "feasting" (Figure 8c) as well as $y a x-k$ 'an, literally "green-yellow," or more broadly "unripe-ripe," for "abundance, bounty" (Figure 8d; see Houston and Stuart 2001:69; Law 2012:275-277). In combination, diverse ethnohistorical and epigraphic sources clearly indicate that bees held and continue to hold a very privileged position in Maya culture, as the vital source of honey at the nexus of rituals and worldview. 


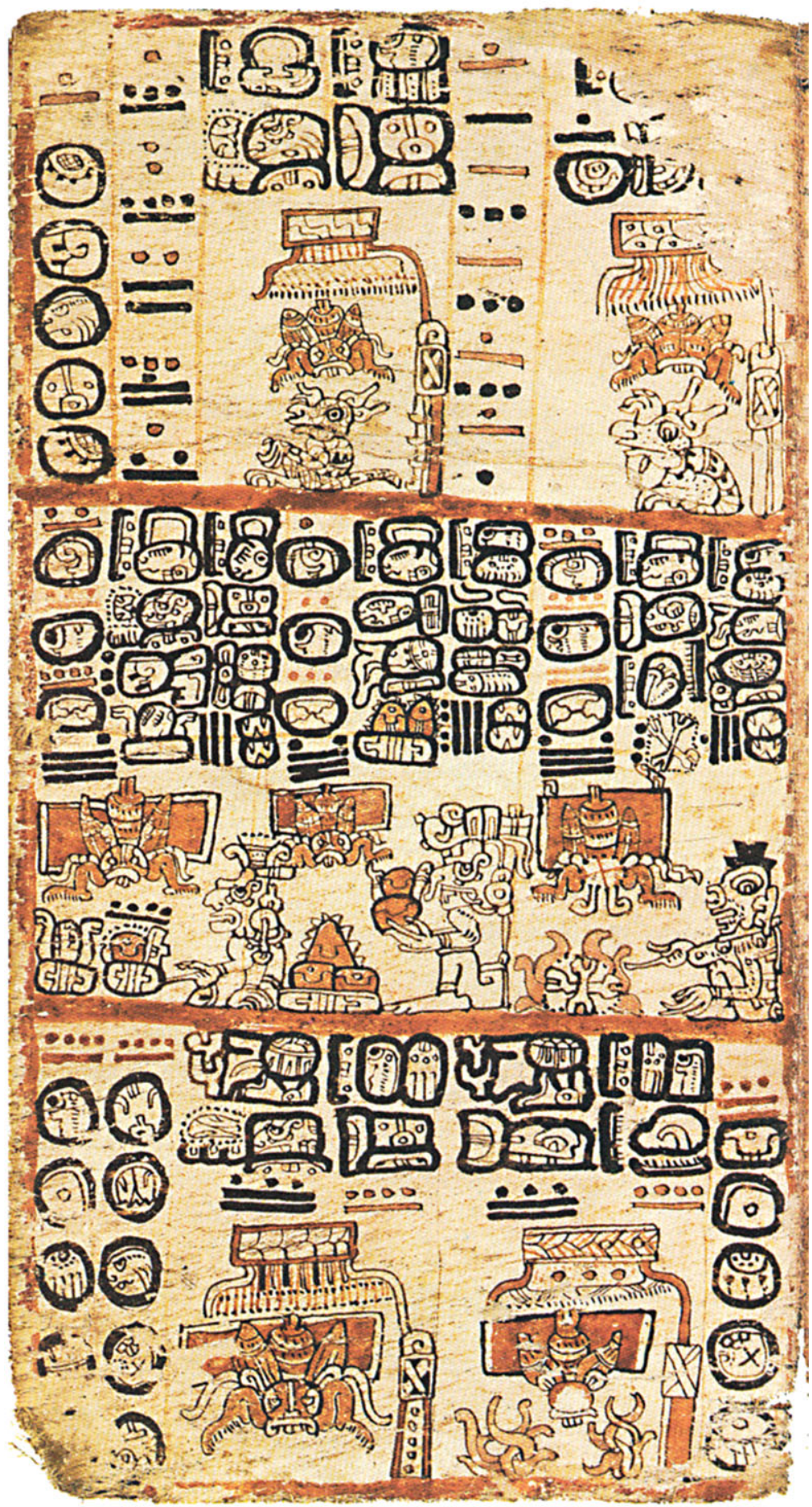

Figure 7. Page 103 of the Madrid Codex showing the juxtaposition of named days and coefficients of the Tzolk'in in the first column of both the upper and lower register. In both the lowest and upper register, the calendrics introduce two small vignettes showing the good and adverse auguries, respectively. (Color online) 

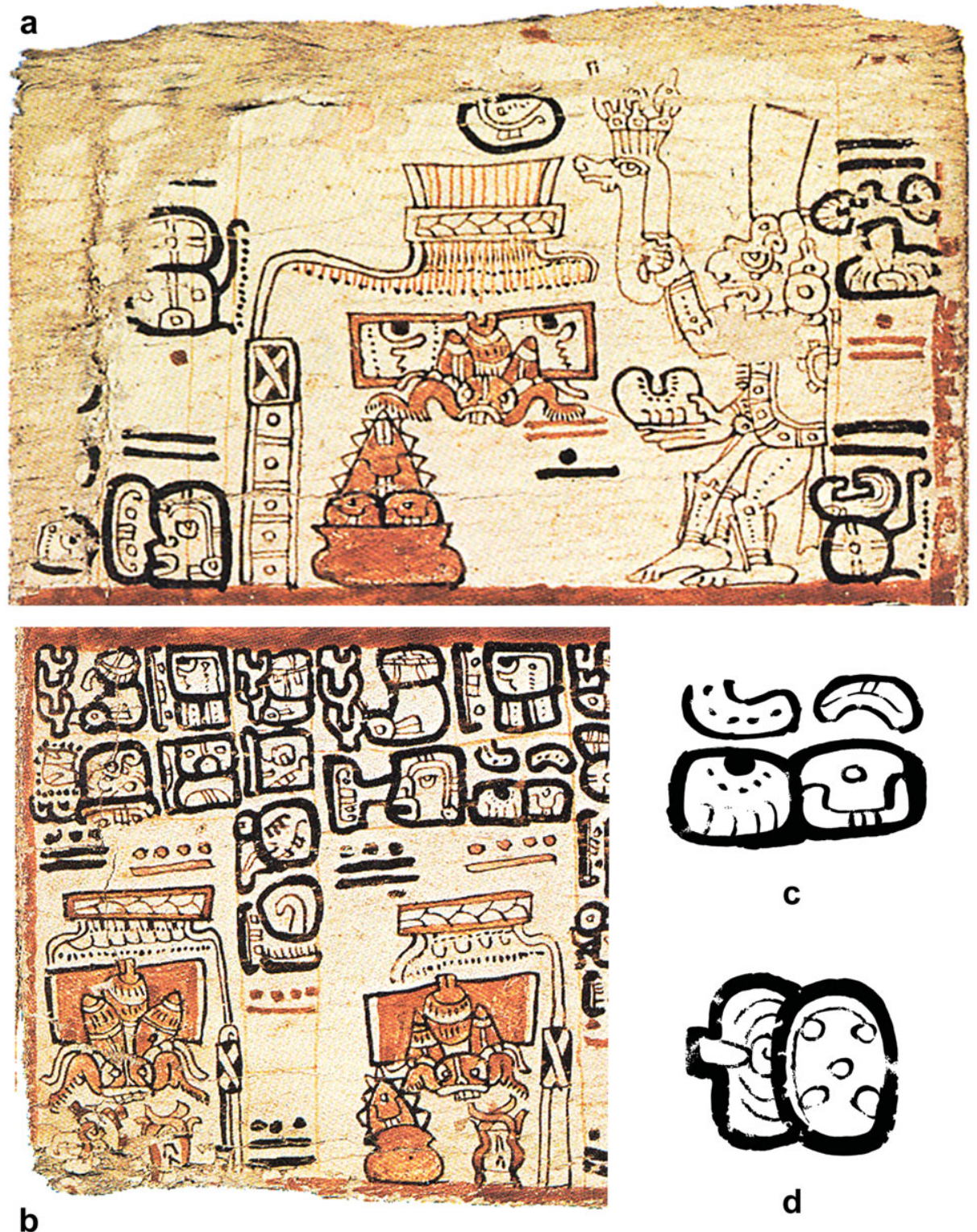

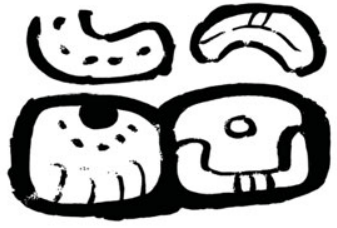

C

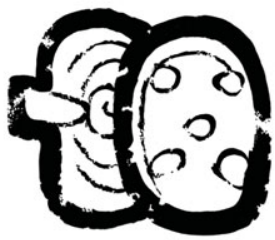

d

Figure 8. a) The deity Itzamnaj officiating a ritual in front of a beehive by sprinkling a substance with a hyssop made of rattlesnake tails (p. 106 upper register). b) Detail of the Madrid Codex showing bees emerging in front of a log hive, sheltered in a small, thatched house, labeled in the glyphic caption as otoch ukab, "home of the bees" (p. 106 lower register). c) The kenning, or difrasismo, $u k$ '-we' literally "drink-eat" for "feasting" (p. 105 upper register) and d) yax-k'an, literally "green-yellow", or more broadly "unripe-ripe," for "abundance”" (p. 110 middle register; drawings by Christophe Helmke). (Color online)

\section{Conclusions}

Honey served as the ultimate sweetener in preindustrial societies, and the Maya were no exception. That it was bee-honey that served as this source of sweetness is made clear in Mayan languages, where the same lexeme means "bee" as well as "honey." With the introduction of European sugar, the semantic domain of the original cognates $k a a b \sim k a b$ was initially 
broadened to encompass the more recent import. Eventually Maya terms underwent a now wellknown shift, wherein European imports were anchored to the original cognates, requiring the displaced autochthonous elements to be referred to by neologisms and loanwords. Thus, in much the same way as keej is now "horse" in K'iche' (originally "deer;" Campbell 2013:232) and iis now frequently means "potato" in Eastern Mayan (formerly restricted to camote or "sweet potato"), so too is $k a b \sim c h a b$ now increasingly "sugar" and "sweet" (Kaufman 2003:583-584, 676-677, 1134-1135). The original "honey" ever more appears in qualified compound form, such as te'el-chab, literally "forest-honey" in Chontal (Pérez González and de la Cruz 1998:136), chukox-chab, literally "honeycomb-honey" in Ch'ol (Becerra 1937:25), or even as the uneasily contrived miyel-kab in Q'eqchi'-including the loanword miel or "honey" from Spanish (see also Kaufman 2003:677).

Based on ethnohistorical data, we know that beekeeping constituted an important activity among the Maya, especially in Yucatan. But, because most beehives in precolumbian times were made of tree trunks, as they are today, it is very difficult to trace ancient apiculture archaeologically. In this context, the artifact from Nakum Offering 9 described here constitutes a very rare find. Found within a large platform, its context suggests its use as a foundation offering related to the construction of a new building or important architectural remodeling. The reason the Maya placed this object within the cache remains unknown, but it might have been associated with a deity or deities that would be propitiated by such an offering. Specific times of the year were dedicated to such supernatural beings, so the ritual placement of this object in a cache might have been aimed at increasing the future harvest of honey. All data indicate that as far as the form, proportions, and other elements of the ceramic cylinder found in Offering 9 are concerned, it can be strictly related to beekeeping of native stingless bees. The object may be a visual representation of a horizontal beehive, or it might have been used as such by the Precolumbian Maya. If our hypothesis is correct, the Nakum piece represents a real or symbolic beehive, making it the oldest in the Maya area and one of the oldest in all of Mesoamerica. Its proportions are consistent with use as a real beehive made of ceramic, although it seems that most precolumbian hives were made of perishable wood. This find demonstrates not only the antiquity of beekeeping in Mesoamerica, but also the very sacred function that the Maya attributed to certain species of native bees.

Acknowledgments. Research at Nakum was made possible thanks to permission from the Ministry of Culture and Sports of Guatemala and the Institute of Anthropology and History of Guatemala (IDAEH). Recent research was financed by the National Science Centre of Poland (under the agreement no. UMO-2014/14/E/HS3/00534). We are very grateful to Estella Weiss-Krejci for drawing our attention to the publication by Rudolf Virchow. We also are grateful for the comments provided by two anonymous reviewers. Thanks also to Harri Kettunen for discussions pertaining to the Q'eqchi' neologism for honey and to Lorraine Williams Beck for allowing us to use her photographs of modern beehives in Yucatan.

Data Availability Statement. The ceramic beehive from Structure 99 at Nakum remains in controlled storage at the National Museum of Archaeology and Ethnology in Guatemala City. Field notes for the 2006-2016 field seasons of the NAP are on file with the Institute of Archaeology, Jagiellonian University, Krakow, Poland, and are available upon request.

\section{References Cited}

Ayala, Ricardo, Victor H. Gonzalez, and Michael S. Engel 2013 Mexican Stingless Bees (Hymenoptera: Apidae): Diversity, Distribution, and Indigenous Knowledge. In Pot-Honey: A Legacy of Stingless Bees, edited by Patricia, Vit, Silvia R. M. Pedro, and David W. Roubik, pp. 135-152. Springer, New York.

Báez-Jorge, Félix

1988 Los oficios de las diosas. Universidad Veracruzana, Xalapa.

Barrera Vásquez, Alfredo

1980 Diccionario Maya Cordemex: Maya - Español, Español-Maya. Ediciones Cordemex, Mérida.

Bastarrachea Manzano, Juan R., Ermilio Yah Pech, and Fidencio Briceño Chel

1992 Diccionario Básico: Español / Maya / Español. Maldonado Editores, Mérida.

Batun, Alpuche, Adolfo Ivan

2009 Agrarian Production and Intensification at a Postclassic Maya Community, Buena Vista, Cozumel, Mexico. Unpublished $\mathrm{PhD}$ dissertation, Department of Anthropology, University of Florida, Gainesville.

Becerra, Marcos E.

1937 Vocabulario de la lengua chol. Publicaciones del Museo Nacional de México. Talleres Gráficos de la Nación, Mexico City. 
Bolles, David

1982 Two Yucatecan Mayan Ritual Chants. Mexicon 4(4):65-68.

Brady, James Edward

1989 An Investigation of Maya Ritual Cave Use with Special Reference to Naj Tunich, Peten, Guatemala. Unpublished PhD dissertation, Department of Anthropology, University of California, Los Angeles.

Bricker, Victoria R.

1997 The Structure of Almanacs in the Madrid Codex. In Papers on the Madrid Codex, edited by Victoria R. Bricker and Gabrielle Vail, pp. 1-25. Middle American Research Institute Publication, Vol. 64. Tulane University, New Orleans.

Bricker, Victoria R., and Gabrielle Vail (editors)

1997 Papers on the Madrid Codex. Middle American Research Institute Publication, Vol. 64. Tulane University, New Orleans.

Buti, David, Davide Domenici, Costanza Miliani, Conception García Sáiz, Teresa Gómez Espinoza, Feliz Jímenez Villalba, Ana Verde Casanova, A. Sabía de la Mata, Aldo Romani, Federica Presciutti, Brenda Doherty, Bruno Giovanni Brunetti, and Antonio Sgamellotti

2014 Non-invasive Investigation of a Pre-Hispanic Maya Screenfold Book: The Madrid Codex. Journal of Archaeological Science 42:166-178.

Campbell, Lyle

2013 Historical Linguistics: An Introduction. 3rd ed. Edinburgh University Press, Edinburgh.

Chuchiak, John F. IV

2004 Papal Bulls, Extirpators, and the Madrid Codex: The Content and Probable Provenience of the M. 56 Patch. In The Madrid Codex: New Approaches to Understanding an Ancient Maya Manuscript, edited by Gabrielle Vail and Anthony Aveni, pp. 57-88. University Press of Colorado, Boulder.

2005 In Servitio Dei: Fray Diego de Landa, the Franciscan Order, and the Return of the Extirpation of Idolatry in the Colonial Diocese of Yucatán, 1573-1579. The Americas 61(4): 611-646.

Ciaramella, Mary A.

1999 The Weavers in the Codices. Research Reports on Ancient Maya Writing 44:29-50.

2002 The Bee-Keepers in the Madrid Codex. Research Reports on Ancient Maya Writing 52:1-68.

2004 The Idol-Makers in the Madrid Codex. Research Reports on Ancient Maya Writing 54:1-18.

Dardón, María José, Carlos Maldonado-Aguilera, and Eunice Enríquez

2013 The Pot-Honey of Guatemalan Bees. In Pot-Honey: A Legacy of Stingless Bees, edited by Patricia Vit, Silvia R. M. Pedro, and David W. Roubik, pp. 395-408. Springer, New York.

de Landa, Fray Diego

1566 Relación de la Cosas de Yucatán. Manuscript in the collections of the Biblioteca de la Real Academia de Historia de Madrid, Madrid.

García Magdaleno, Pavel Alonso

2013 Balam cab. Las abejas silvestres y su simbolismo entre los mayas. Degree dissertation, Facultad de Filosofía y Letras, Colegio de Historia, Universidad Nacional Autónoma de México, Mexico City.

Hellmuth, Nicholas

1992 A Report to IDAEH on Four Days Research at Nakum. Foundation for Latin American Anthropological Research, Guatemala City.
Helmke, Christophe G.B

2009 Ancient Maya Cave Usage as Attested in the Glyphic Corpus of the Maya Lowlands and the Caves of the Roaring Creek Valley, Belize. Unpublished $\mathrm{PhD}$ dissertation, Institute of Archaeology, University College London, London.

Hermes, Bernard

2002 Síntesis preliminar de la ocupación prehispánica en el área central de Nakum. Beiträge zur Allgemeinen und Vergleichenden Archäologie 22:277-285.

Hermes, Bernard, and Zoila Calderón

2003 La secuencia de ocupación prehispánica en Nakum: Una visión preliminar. In XVI Simposio de Investigaciones Arqueológicas en Guatemala, 2002, edited by Juan Pedro Laporte, Bárbara Arroyo, Héctor Escobedo, and Héctor Mejía, pp. 305319. Museo Nacional de Arqueología y Etnología, Guatemala City.

Houston, Stephen, and David Stuart

2001 Peopling the Classic Maya Court. In Royal Courts of the Ancient Maya, Vol. 1, edited by Takeshi Inomata and Stephen D. Houston, pp. 54-83. Westview Press, Boulder.

Imre, Dylan M., Lisa Young, and Joyce Marcus

2010 Ancient Maya Beekeeping (ca. 1000-1520 CE). University of Michigan Undergraduate Research Journal 7:42-50.

Kaufman, Terrence

2003 A Preliminary Mayan Etymological Dictionary. Foundation for the Advancement of Mesoamerican Studies, Inc. Electronic document, http://www. famsi.org/reports/01051/pmed.pdf, accessed May 24, 2015.

Kováč, Milan, Eva Jobbová, and Guido Krempel

2016 The Legacy of an Early Maya King: Text, Imagery and Ritual Contexts of a Late Preclassic Cache from Structure H-XVI Sub, Uaxactun. Mexicon 38(1):929

Law, Danny

2012 Appropriating Sacred Speech: Aesthetics and Authority in Colonial Ch'olti'. In Parallel Worlds: Genre, Discourse, and Poetics in Contemporary, Colonial and Classic Maya Literature, edited by Kerry M. Hull and Michael D. Carrasco, pp. 271-282. University Press of Colorado, Boulder.

López Medel, Tomás

1990 De los tres elementos. Tratado sobre la Naturaleza y el hombre del Nuevo Mundo. Edited and transcribed by Berta Ares Queija. Alianza Editorial, Madrid.

Martos López, Luis Alberto

2002 Por las tierras mayas de oriente: arqueología en el área de Calica, Quintana Roo. Instituto Nacional de Antropología e Historia / Consejo Nacional Para la Cultura y las Artes, Mexico City.

Mayer, Karl-Herbert

2009 Traditional Maya Beekeepers at Kiuic, Yucatán, Mexico. Mexicon 31(5):98-101.

Milbrath, Susan

2010 Star Gods of the Maya: Astronomy in Art, Folklore, and Calendars. University of Texas Press, Austin.

Morley, Sylvanus G.

1938-1939 The Inscriptions of Peten. 5 vols. Carnegie Institution of Washington, Washington DC.

Nárez, Jose

1988 Algunos datos sobre las abejas y la miel en la época prehispánica. Revista Mexicana de Estudios Antropológicos 34(1):123-140. 
Nielsen, Jesper, Christophe Helmke, and Maja Balle 2016 Skrevet på papir og skind: Mesoamerikanske manuskripter fra præcolumbiansk tid til kolonitiden. Fund og Forskning 55:9-85.

Noriega, Raúl

1999 Trabajos de restauración en el Templo A de Nakum, Petén. In XII Simposio de Investigaciones Arqueológicas en Guatemala, 1998, edited by Juan Pedro Laporte, Héctor Escobedo, and Ana Claudia Monzón de Suasnávar, pp. 139-146. Ministerio de Cultura y Deportes, Instituto de Antropología e Historia de Guatemala, and Asociación Tikal, Guatemala City.

Noriega, Raúl, and Bernard Hermes

2000 Avance en los trabajos de investigación arqueológica y restauración en los Edificios N, 60 y 61 de Nakum. In XIII Simposio de Investigaciones Arqueológicas en Guatemala, 1999, edited by Juan Pedro Laporte, Héctor Escobedo, and Ana Claudia Monzón de Suasnávar, pp. 419-438. Museo Nacional de Arqueología e Etnología, Guatemala City.

Noriega, Raúl, and Oscar Quintana

2002 Programa de restauración: Proyecto Protección de Sitios Arqueológicos en Petén. In XV Simposio de Investigaciones Arqueológicas en Guatemala, 2001, edited by Juan Pedro Laporte, Héctor Escobedo, and Bárbara Arroyo, pp. 228-238. Museo Nacional de Arqueología y Etnología, Guatemala City.

Quintana, Oscar, and Wolfgang Wurster

2002 Un nuevo plano del sitio Maya de Nakum, Peten, Guatemala. Beiträge Zur Allgemeinen und Vergleichenden Archäologie 22:243-275.

Patel, Shankari

2005 Pilgrimage and Caves on Cozumel. In Stone Houses and Earth Lords: Maya Religion in the Cave Context, edited by Keith M. Prufer and James E. Brady, pp. 91-114. University Press of Colorado, Boulder.

Pérez González, Benjamín, and Santiago, de la Cruz 1998 Diccionario chontal. Chontal-español / Españolchontal. Instituto Nacional de Antropología e Historia, Mexico City.

Périgny, Maurice de

1906 Les ruines de Nacun. La Nature 34(1):360-362.

Restall, Matthew, and John F. Chuchiak IV

2002 A Re-evaluation of the Authenticity of Fr. Diego de Landa's Relación de las Cosas de Yucatán. Ethnohistory 49(3):651-670.

Smith, Robert E., and James C. Gifford

1966 Maya Ceramic Varieties, Types and Wares at Uaxactun: Supplement to Ceramic Sequence at Uaxactun, Guatemala. MARI Publication 28. Middle American Research Institute, New Orleans.

Sotelo, Laura Elena

2002 Los dioses antropomorfos del Códice Madrid. Aproximación a las representaciones antropomorfas de un libro sagrado maya. Unpublished $\mathrm{PhD}$ dissertation, Estudios Mesoamericanos, Universidad Nacional Autónoma de México, Mexico City.

Stuart, David

1998 'The Fire Enters His House': Architecture and Ritual in Classic Maya Texts. In Function and Meaning in Classic Maya Architecture, edited by Stephen Houston, pp. 373-426. Dumbarton Oaks Research Library and Collections, Washington, DC.

Stuart, George E.

1988 Glyph Drawings from Landa's Relación: A Caveat to the Investigator. Research Reports on Ancient Maya Writing 19:23-28.

Suárez Aguilar, Vicente, Heber Ojeda Mas, and Iliana Ancona Aragón

2010 Economía y subsistencia en Playa Esmeralda, Champotón, durante el Preclásico. In XXIII Simposio de Investigaciones Arqueológicas en Guatemala, 2009, edited by Bárbara Arroyo, Adriana Linares Palma, and Lorena Paiz Aragón, pp. 750-766. Museo Nacional de Arqueología y Etnología, Guatemala City.

Taube, Karl

1992 The Major Gods of Ancient Yucatan. Studies in Precolumbian Art and Architecture, No. 32. Dumbarton Oaks Research Library and Collection, Washington, DC.

Tozzer, Alfred

1913 A Preliminary Study of the Prehistoric Ruins of Nakum, Guatemala. Memoirs of the Peabody Museum of Archaeology and Ethnology Vol. 5(3):137201. Harvard University, Cambridge, Massachusetts.

1941 Relación de las Cosas de Yucatán: A Translation. Papers of the Peabody Museum of American Archaeology and Ethnology, Vol. 18. Harvard University, Cambridge, Massachusetts.

Vail, Gabrielle

1994 A Commentary on the Bee Almanacs in the Codex Madrid. In Códices y documentos sobre México, edited by Constanza Vega Sosa, pp. 37-68. Instituto Nacional de Antropología e Historia, Mexico City.

Vail, Gabrielle, and Anthony Aveni

2004 Maya Calendars and Dates: Interpreting the Calendrical Structure of Maya Almanacs. In The Madrid Codex: New Approaches to Understanding an Ancient Maya Manuscript, edited Gabrielle Vail and Anthony Aveni, pp. 131-146. University Press of Colorado, Boulder.

Villanueva-G., Roguel, David W. Roubik, and Wilberto Colli-Ucán

2005 Extinction of Melipona beecheii and Traditional Beekeeping in the Yucatán Peninsula. Bee World 86(2):35-41.

Virchow, Rudolf

1887 Schädel von Merida, Yucatan. Zeitschrift für Ethnologie 19:451-455.

Wallace, Henry

1978 The Strange Case of the Panucho Plugs: Evidence of Precolumbian Apiculture on Cozumel. Unpublished paper. Copy on file at the University of Arizona, Tucson.

Ximénez, Francisco

1967 Historia Natural del Reino de Guatemala. Edited by Ernesto Chinchilla Aguilar, Julio Roberto Herrera S. and Francis Gall. Editorial Jose de Pineda Ibarra, Guatemala City.

Źrałka, Jarosław, Wiesław Koszkul, and Bernard Hermes

2008 Investigaciones en Nakum, Peten, Guatemala: Resultados de las excavaciones realizadas por el Proyecto Arqueológico Nakum en los años 2006 y 2007. Contributions in New World Archaeology 1:73128. 
2012 Nakum y su importancia en el mundo maya: Resultados de los trabajos realizados por el Proyecto Arqueológico Nakum entre 2006 y 2011. Contributions in New World Archaeology 3:9-47.

Źrałka, Jarosław, Wiesław Koszkul, Katarzyna Radnicka, Laura Elena Sotelo Santos, and Bernard Hermes
2014 Excavations in Nakum Structure 99: New Data on Protoclassic Rituals and Precolumbian Maya Beekeeping. Estudios de Cultura Maya 44:85-117.

Submitted June 1, 2017; Revised December 31, 2017; Accepted March 22, 2018 